\title{
A Concept toward Negotiation Support for Value Management on Sustainable Construction
}

\author{
Christiono Utomo (Corresponding author) \\ School of Construction Management, Department of Civil Engineering \\ Institut Teknologi Sepuluh Nopember, Kampus ITS Sukolilo, Surabaya, 60111, INDONESIA \\ Tel: 62-81-7936-5536 E-mail: christionoutomo@gmail.com, christiono@ce.its.ac.id
}

Arazi Idrus

Department of Civil Engineering, Universiti Teknologi PETRONAS

Tronoh Bandar Seri Iskandar Perak, MALAYSIA

E-mail:arazi_idrus@petronas.com.my

Received: December 6, 2010 Accepted: October 26, $2011 \quad$ Published: December 1, 2011

doi:10.5539/jsd.v4n6p56

URL: http://dx.doi.org/10.5539/jsd.v4n6p56

\begin{abstract}
Decision making for value-based design in Value Management (VM) is very complicated due to the involvement of many parties. In such situation where the designer, project manager, facility manager and others are involved in choosing a single alternative from a set of solutions, a negotiation support is required to evaluate and rank the solution before engaging into negotiation. This paper presents a conceptual model of negotiation support for VM. It consists of developing the appropriate research approach, methodology of negotiation and agent-based negotiation in VM. The research objectives are to find a theoretical basis and research approach for negotiation support methodology on VM, to develop a decision model for technical solution options in a satisfying function/cost preferences, to investigate negotiation style and outcome and analyze the correlation between them for the basis of scenarios on the agent system, to develop a model for agreement options and coalition algorithms on value-based decision, to validate the coalition algorithms and introduce an initial model of Negotiation Support for Value Management (NSVM). A triangulation methodology has been used to fulfill the objectives. It combines simultaneous triangulation by using case studies and survey methods and sequential triangulation in which results of one method are essential in planning the next method (theoretical mapping, survey research, focus group, case study and conceptual modeling). The methodology is based on a theoretical approach which consists of value-based decision nature in construction $\mathrm{VM}$, multicriteria group decision making, game theory, negotiation theory, and agent-based development. This methodology combines value analysis method using Function Analysis System Technique (FAST); Life Cycle Cost analysis, group decision analysis method based on Analytical Hierarchy Process (AHP), and Game theory-based agent system to develop a negotiation support. The negotiation support bridges theoretical gap between automated design in construction domain and automated negotiation in information technology domain by providing a structured methodology which can lead to systematic support system and automated negotiation for VM process. It will contribute to the Value Management body of knowledge as an advanced method for creativity and analysis phase, since the practice of this knowledge is teamwork based.
\end{abstract}

Keywords: Negotiation support, Value Management, Sustainable Construction

\section{Background and Motivation}

Different project participants and often geographically distributed (Sense, 2008; Ng et al., 2005; Evaristo et al., 2004; Nidiffer \& Dolan, 2005), need to cooperate and collaborate to perform various construction activities. Howard et al. (1989) and Ghanbari (2006) notes that construction projects are characterized by their complexity, which provides the basis for fragmentation in the AEC/FM (architecture, engineering, construction, and facility management). In the context of decision making, the decision criteria of the many stakeholders keep increasing in terms of both number and complexity (Kumaraswamy, 2004). A better understanding of collaborative engineering principles will lead to more effective design and use of complex systems composed of people, corporate knowledge, engineering processes, and automation technology (Parker, 2000; Huang et al., 2006). 
One of the collaborative activities in construction practices is Value Management (VM) as collaborative design which is an activity in which multiple stakeholders are involved as it requires multiple bodies of knowledge (Woodhead, 2007). VM is multidisciplinary, seeking to maximize the creative potential of all departmental and project participants working together. Venkataraman and Pinto (2008) wrote that the key to effective VM is to involve all appropriate stakeholders in a process of structured team thinking, so that the needs of the main parties can be accommodated wherever possible. The involvement depends on the level and stage of the VM process. The cross-functional framework of VM ensures that there is improved communication, teamwork, and a shared understanding among the key participants. VM becomes an approach that enhances the communication of a common understanding between team members as to project's fundamentals. In the natural characteristic of construction industry, it means that a tool for decision team is necessary. Hence, negotiation will be appropriate for decision process on VM.

\section{Project Value Objectives and VM}

The reasons that projects need VM come from many researchers and practitioner (Venkataraman \& Pinto, 2008). First, VM prevent the poor definition of a project goal that affects cost and time overruns. It is also prevent long-term user dissatisfaction by forcing organization to identify the need for, and scope of, any project at the earliest possible stage. Second VM attempts to eliminate elements that contribute to poor project value by developing an understanding of the VM processes in all project participants.

There are infinite varieties of definitions for the term "value" (Kaufman, 2001). "Value" can be defined as a measure of how well the owner's objective are met and is typically documented as a set of project objectives. The owner's ability to understand, prioritize, and articulate project value objectives is critical to overall project success (Kerzner, 2003; Cha, 2003). The right combination of project value objectives is the set of objectives that will provide an optimum value for the owner. Therefore, the concept of value in the context of a capital project should be established by the project owner to reflect unique business goals, project objectives, need, and desires (Leung et al., 2002).

In this paper, these processes are referred to as Value-based Design Decision (VDD) in VM. VDD is an organized effort directed in VM techniques to analyze the functions of systems, equipment, facilities, services, and supplies for achieving the essential function at the lowest life cycle cost consistent with the required performance, reliability, quality and safety (Kelly et al., 2004; Kaufman, 2001). This is inline with the statements made by Shen and Liu (2004) which stated VM in construction is increasingly seen as the term to describe the total process of enhancing a project value from concept to operation.

Li et al. (2004) reported that, both analytical modeling and simulation methods in performance evaluation made a significant progress over the past few years. Further they argue that "whilst cost is an important consideration, it is only one of the parameters influencing the decision process, and therefore, cannot be considered in isolation". Currently, there is no single individual or set of VM that ensure the best value of a project in all situations. In addition, the vast majority of available VM are impractical to implement on a single project (Lenzer, 2001; Kaufman \& McCuish, 2002). Thus, VM should be selected based on the needs of an individual project or a set of circumstances. Factors such as uniqueness, size, complexity, resource ability, and location can make dramatic difference in the appropriateness and effectiveness of any individual VM.

\section{The Requirements of Negotiation Support for VM}

VM is a structured and analytical process that seeks to achieve value by identifying all necessary functions at the lowest cost, while maintaining with the required levels of quality and performance (SAVE International, 2001). It also means that VM identifies and eliminates unnecessary cost based on function analysis (Mukhopadhyaya, 2003; Younker, 2003). Unnecessary cost is cost with contributed nothing to quality, use, life cycle appearance or desired customer feature. It is nature on design process.

VM has been widely adopted in many countries over several decades as a very effective tool to meet the increasing demands for value enhancement by clients (Dell'Isola, 1982; Kirk \& Spreckelmeyer, 1988; Basha \& Gab-Allah, 1991; Barton, 2000; Liu, 2003; Jaapar et al., 2009; Cheah \& Ting, 2005; Wan, 2006, Lin \& Shen, 2007). Value-based decision is an effort of VM process. It improves the value of a facility through identifying opportunities to remove unnecessary costs.

$\mathrm{VM}$ is seen as a process that involved multi disciplines and teamwork effort, hence, negotiation becomes an important role in the value-based decision process of a component or an element or a building system. A support system is required for negotiation in value-based decision on VM process. It can start from a function analysis system technique (FAST) to get the attributes of the function. The attributes will become the criteria in the decision 
making process. A pair-wise comparison can be used as a method in the decision process since each stakeholder or decision maker has his/her own preference.

VM process will be facilitated by the implementation of an agent system and it will help to reduce cost and to improve value of building system decision in construction projects. It will also bridge the gap between automated design which were identified earlier by Anumba, et al. (2002), Kim \& Russel (2003), Halfawy (1998), Khedro (1994), Ugwu et al. (1999) on the construction domain in relation to automated negotiation (Matsatsinis \& Delias, 2003; Morge \& Beaune, 2004; Wanyama, 2006; Wanyama \& Far, 2007; Vo \& Padgham, 2007) in Information Technology (IT) domain. This significance of the framework is illustrated in Figure 1.

Many researchers suggested applying Game Theory in automated negotiation (Binmore \& Vulkan, 1999). However, the negotiation support model for VM processes has not been developed. The characteristic of value criteria cannot be applied to previous research. Existing models that are commonly accepted are optimization-based models, for example aggregation methods, but these are not able to solve the problem of value criteria on VM. This concept of negotiation support applies the satisfying game method where function and cost of solution techniques for a building system as value criteria can be formulated on coalition algorithms.

\section{The Need of Agent-based Negotiation for VM}

An agent system (Bond \& Gasser, 1988) provides a decentralized approach to modeling the fragmented construction engineering and management problems. Such fragmented problems, though widely recognized, are difficult to be solved using other approaches. Ugwu et al. (1999) writes that the idea of incorporating agent system into the construction industry provides a novel approach in tackling distributed problems. The solution from agent system will lead to better quality, more economical, safer and more optimal solutions (Ugwu et al., 1999). The additional problems posed by the use of heterogeneous software tools are well known and need to be overcome by the adoption of new approaches, such as the use of Intelligent Agent (IA). IA consists of self-contained knowledge based (k-b) systems that are able to tackle specialist problems and can interact with one another (and/or with humans) within a collaborative framework (Anumba et al., 2005).

In a system composed of multiple autonomous agents, negotiation is a key form of interaction that enables groups of agents to arrive at a mutual agreement regarding belief, goal or plan (Beer et al., 1999; Ren \& Anumba, 2004). Particularly, because agents are autonomous and in many cases, are self-motivated, they must influence and convince others to proceed in certain ways. Negotiation is used more specifically for conflict resolution (Pena-Mora \& Wang, 1998), task allocation, resource allocation, and decision making (Hamel et al., 2005). The potential benefits of agent negotiation include saving time and money, efficiency for computation intense negotiations in search for optimal results, and the ability to incorporate multiple negotiation strategies for changing environments (Anumba et al., 2005). Bogg et al. (2008) notes why interest in agent system is increasing. It is because of its ability to provide robustness and efficiency, to allow extending legacy systems and to solve problems in which data, expertise or control are distributed. Even though research in the application of agent-based negotiation in construction industry has been extensive, none of them has focused on multi-criteria agent-based negotiation.

The aim of this paper is to define a concept of negotiation support model for multi-criteria group decision making in the process of VM applications in sustainable construction. The significance of achieving the objectives and its contributions are to provide an approach for a better decision-making which will improve the value of construction projects and to provide a framework for facilitate of automated negotiation in a collaborative negotiation between all parties in a value-based design decision. The negotiation support system concept will bridge the theoretical gap between automated design and automated negotiation, It is also contributes to the body of knowledge in the decision-making science domain by initiating an advanced tool for negotiation by providing an advanced method in phase of creativity and analysis in VM process since the practice of VM knowledge is teamwork-based.

The methodology for the negotiation support system on VM is developed based on the concept. It can assist VM to conduct negotiation process in its practices. It means that this methodology contributes to VM body of knowledge by adding a negotiation process to the practice of VM. The results from its application on building system selection on VM also contributes to the group decision and negotiation process of the American Society for Testing and Materials (ASTM) Standard, Book of Building Economics (ASTM, 2004).

The coalition algorithms developed in this research can be used for any development research on group decision and negotiation in VM within the construction industry. Negotiation support model arising from this research gives contribution for a better application of multi-discipline and teamwork on VM practice. As the area of the research covers the domain of VM, construction, operation research and Artificial Intelligence (AI), the support 
model also contributes to the development of research on these areas.

\section{Theoretical Basis}

Based on the literature review of previous research works, a theoretical mapping can be developed to show the position of the present research in the domain of knowledge. On the first level, there are four domains of science and knowledge namely value management, decision science, and negotiation theory and agent system. The second level consists of three research domains based on the intersection of each of the knowledge on the first level. The research domains are: first, value based decision which comes from the application of decision science on VA, VE, VM; second, group decision and negotiation from decision theory and negotiation theory; and third, automated negotiation. Many examples of research in the three areas have been reported. The third level consists of two research domains. One is combining value-based decision and group decision in the field of VA, VE, and $\mathrm{VM}$, the other is combining agents and negotiation. Both research areas are in the context of multi-criteria environment. The research reported in this paper is derived from the intersection of the two knowledge domains of value based management and agent based negotiation.

This theoretical basis not only shows the position of the research on theoretical domain but also as the basis of for negotiation support on VM. This review has also become a basis for building the framework of negotiation support for VM. A clear theoretical mapping gives a better understanding of the significance of this research and area of contribution to the body of knowledge. The review on literature and previous research works also has identified a theoretical gap between automated negotiation and automated design, both of which have limitations. Automated negotiation is limited to determining preferences and technical solutions, where research in this area focuses on algorithm of automation of negotiation. On the other hand, automated design is limited to the application of traditional negotiation method on the strategic level of a design decision.

A comprehensive literature review has been conducted based on previous related studies in VM, group decision including game theory, and automated negotiation including agent-based negotiation and combination multi criteria and agent system. It reviewed comprehensive previous researches in computer tolls for VM, protocol negotiation on agent system and agent negotiation on construction industry. Based on the findings of the literature review, negotiation in VM is seen to be a complex and dynamic process in which all stakeholders aim to get the best solution for all. There are three schools of thoughts concerning negotiation on value based design decision. The first considers the teamwork process in VM; the second considers group decision theory; and the third considers automated negotiation theory.

A theoretical mapping, which becomes the theoretical basis for this research has also been developed from the literature review. The theoretical gap between automated negotiation and automated design provides the opportunity for research to be undertaken. Furthermore, the review also reveals that there has not been any work in negotiation support for group decision in VM, which has been one of the motivations for this research. Based on the theoretical basis, a methodology for developing of NSVM was built.

\section{Methodological Approach, Ontological, and Epistemological Issues}

There are two types of research strategies namely 'quantitative research' and 'qualitative research'. The first research uses numbers and statistical methods, and the second research focus and involves an interpretive, naturalistic approach to its subject matter. The former is based on numerical measurements of specific aspects of phenomena. Abstracting from particular instances to seek general descriptions or to test causal hypotheses, it seeks measurements and analyses that are easily replicable by other researcher (King et al., 1994). The latter involves the use and collection of a variety of empirical materials - case study, personal experience, introspective, life story, interview, observational, historical, interactional, and visual texts - that describe routine and problematic moments and meanings in people's lives (Denzin \& Lincoln, 1994).

Morgan and Smircich (1980) argued that the choice of research instrument also depends on critical skills of applied philosophical awareness rather than methods-level decision-making. The choice and adequacy of a method embodies a variety of assumptions regarding the nature of knowledge and the methods through which that knowledge can be obtained, as well as a set of root assumptions about the nature of the phenomena to be investigated. All approaches to science are based on interrelated sets of assumptions regarding ontology, human nature and epistemology (Burrell \& Morgan, 1979). There is a relationship between ontology, epistemology and methodology.

Ontology has been described as 'a theory which claims to describe what the world is like - in a fundamental, foundational sense - for authentic knowledge of it to be possible (Barnes \& Gregory, 1997), or in the simple word of Gruber (1993) is a specification of a conceptualization. It can be understood as assumptions about the 
nature of reality (Philimore \& Goodson, 2004).

Epistemology in its general form is a study of knowledge through which 'rules' can be established to identify what is to be counted as 'true' (Barnes \& Gregory, 1997). Epistemology is the study of method for acquiring knowledge. It encompasses the nature of concepts, the formulation of concepts, the validity of the senses, logical reasoning, as well as thoughts, ideas, memories, emotions, and all things mental. It is concerned whether these relationships are valid (Landauer \& Rowlands, 2006). The epistemology focuses on analyzing the specific processes through which reality is created.

Researchers should be flexible and therefore they are recommended to select a variety of methods rated appropriate to the research problem under investigations (Burgess, 1984). Modern-day scientific approach is inductive and deductive, as well as objective and subjective. Design validity is more likely to be built into the research study when the researcher is open to both paradigms than when one or the other is precluded. In this research, quantitative approaches used include questionnaire survey while qualitative approaches adopted include focus group and case study; the two approaches were used to complement each other.

Fellow and Liu (2008) wrote that triangulation in construction research is the use of two or more research methods to investigate something. They gave samples which are experiments and interviews in a case study project. Six years before, Love et al. (2002) proposed and introduced triangulation in construction management research. Their suggestion is to answer debate in the construction management (CM) research literature as to which research methodology is the most appropriate for CM research problems. They argued that post modernity and multi-level research can extend the scope of CM theory. Many researchers suggest that triangulation is a research technique which employs both quantitative (validation) and qualitative (inquiry) studies. From this point, Thurmond (2001) gives detailed definition. By referring to Denzin (1970) and Kimchi et al. (1991), Thurmond explained that Triangulation is the combination of two or more data sources, investigators, methodological approaches, theoretical perspectives, or analytical methods within the same study. These combinations result in data triangulation, investigator triangulation, methodological triangulation, theoretical triangulation or analytical triangulation.

Dainty (2008) put "triangulation" in the classification of multi-strategy research in Methodological Pluralism. Consisting of "complementary" and "facilitation", "triangulation" refers to the use of qualitative research to corroborate quantitative research, whereas the complementary refers to "is where one research strategy is employed in order to aid research using another approach" while facilitation refers to "is where two strategies are employed in order to dovetail different aspects of an investigation".

Further, Jacobsen (2004) defines the term 'combination in Triangulation' into two kinds which are Simultaneous Triangulation by the use of both qualitative and quantitative methods at the same time and Sequential Triangulation in which the results of one method are essential for planning the next method. This approach involves using more than one research method and data collection technique, because each addresses a different dimension of the problem in developing the NSVM. Two kinds of Triangulation by Jacobsen (2004) were applied. By Simultaneous Triangulation, five methods give result to develop the NSVM model (Tabel 1). Literature review and mapping theory give a theoretical basis and build the methodological approach for NSVM model. Qualitative research is conducted through Focus Group and Case Study methods. Both methods generated satisfying options for value-based decision. A generic decision model for the foundation of the NSVM model was built. Quantitative research is conducted through Survey and Conceptual Modeling. The result from the survey is a mathematical model of correlation between negotiation styles and negotiation outcomes among managers in the construction industry in Malaysia and Indonesia. Conceptual modeling reveals a basis of algorithm for NSVM.

By Sequential Triangulation, the result of literature review is used for research approach. The research approach is the basis for Focus Group and all of seven case studies in the next stage. The data on the function and life cycle cost of technical solution for building system which was obtained from the Focus Group research were applied to these case studies. These data are also applied for Conceptual Modeling. The result from the survey conducted is used to the algorithms on Conceptual Modeling. The process to fulfill these objectives also follows the simultaneous and sequential Triangulation.

\section{Conclusion}

Through a comprehensive literature review, the research demonstrates a theoretical mapping as a basis for NSVM. Based on the theoretical mapping, a framework of methodology for NSVM has been developed for the study. The methodology involves the concept of value-based decision in VM within a construction project, group choice in multi-criteria decision making, and coalition formation in Game Theory. This methodology combines 
value analysis method, decision method and agent-based negotiation. The methodology represents the knowledge and process of group decision making and negotiation in VM process. The literature review and the development of the theoretical foundation revealed that coalition formation in Game Theory is useful to address the negotiation support model.

Generally, it is important that research continues in the area of VM, operation research and agent-based technology. There is an urgent need for a greater recognition of the validity and importance of naturalistic inquiry within the building economics and construction management research community. Whilst this research has developed the theoretical and philosophical basis of negotiation support for VM, there is considerable amount of work which remains to be done within the wider domains of building economics, construction management, operation research and agent-based negotiation and technology. Within the specific field of VM, there is need for further research into the possible application of other methodologies of group decision support and negotiation support. In the domain of operation research, there are a lot of opportunities for mathematical proof research for optimization and satisfying decision in cooperative and incomplete information environments. A mathematical proof research for an unlimited multi-person decision maker in a project involving a whole community as in many infrastructure projects today will be an interesting research since VM becomes a wider application in many fields as the construction of infrastructure projects becomes more complex.

Future research in the field of agent-based negotiation and management will have a huge benefit from the development of a user-friendly software which uses a GUI (graphical user interface), but it will surely consume a lot of time and money for research. In future, the combination of many technologies such as Virtual Reality (VR) will help human and its agent to communicate, discuss and make decision for any type or stages of building system design with two main important preferences that are function and cost. As to further illustrate, a final building design decision can be made by an agent from all the project participants in a virtual reality environment simultaneously while being in a different geographical area. This research provides basic and conceptual algorithms to bridge automated design decision, and automated negotiation by applying a systematical design method in construction, that is, VM.

\section{Acknowledgment}

The writers appreciate the recognition and awards in forms of research grant and fellowship from "Program Penelitian Kerjasama Internasional ITS 2011" Indonesia and Universiti Teknologi PETRONAS Malaysia. The writers are also grateful to Farida Rahmawati, Isnanto, Hanifah Nebrian Sukma, and Annisa Nugraheni for their support.

\section{References}

Anumba, C. J., Ugwu, O. O., Newnham, L. \& Thorpe, A. (2002). Collaborative design of structures using intelligent agents. Automation in Construction. 11, 89-103. http://dx.doi.org/10.1016/S0926-5805(01)00055-3

Anumba, C. J., Ugwu, O. O. \& Ren, Z. (2005). Agents \& Multi-Agent System in Construction. Taylor and Francis, London.

ASTM. (2004). ASTM Standards on Building Economics: $5^{\text {th }}$ edition. ASTM International.

Barness, T. \& Gregory, D. (1997). Reading Human Geography: the Poetics and Politics of Inquiry. Arnold, London.

Barton, R. T. (2000). Soft value management methodology for use in projection initiation - a learning journey. Journal of Construction Research. 1 (2), 109-122.

Basha, I. M. \& Gab-Allah, A. A. (1991). Value engineering in Egyptian bridge construction. Journal Construction Engineering and Management. $117 \quad$ 393-401. http://dx.doi.org/10.1061/(ASCE)0733-9364(1991)117:3(393)

Beer, M., D'inverno, M., Luck, M., Jennings, N., Preist, C. \& Schroeder, M. (1999). Negotiation in multi-agent systems. The Knowledge Engineering Review. 14 (3), 285-289. http://dx.doi.org/10.1017/S0269888999003021

Binmore, K. \& Vulkan, N. (1999) Applying game theory to automated negotiation. NETNOMICS. 1 (1), 1-9. Springer Netherlands. http://dx.doi.org/10.1023/A:1011489402739

Bogg, P., Beydoun, G. \& Low, G. (2008). When to use a multi-agent system? Lecture Notes in Computer Science 5357/2008: 98-108. Springer Berlin / Heidelberg.

Bond, A. H. \& Gasser, L. (1988). Reading in Distributed Artificial Intelligence. Morgan Kauffamn, San Mateo, CA. 
Burgess, R. G. (1984). In the Field: An Introduction to Field Research. George Allen and Unwin, London. http://dx.doi.org/10.4324/9780203418161

Burrell, G. \& Morgan, G. (1979). Sociological Paradigms and Organizational Analysis. Heinemann Educational Books, London.

Cha, H. S. (2003). Selecting Value Management Processes for Implementation on Capital Facility Projects. Ph.D. dissertation. The University of Texas at Austin.

Cheah, C. Y. J. \& Ting, S. K. (2005). Appraisal of value engineering in construction in Southeast Asia. International Journal of Project Management. 23, 151-158. http://dx.doi.org/10.1016/j.jproman.2004.07.008

Dainty, A. (2008) Chapter one: methodological pluralism in construction management Research. In: Knight and Ruddock (Eds.). Advanced Research Methods in the Built Environment. Oxford: Wiley-Blackwell, pp.1-13.

Dell'Isola, A. J. (1982). Value Engineering in the Construction Industry, Van Nostrand Reinhold, New York.

Denzin, N. K. (1970) The research act in sociology: A theoretical introduction to sociological methods. Aldine Publishing, Chicago.

Denzin, N. K. \& Lincoln, Y. S. (1994). Handbook of Qualitative Research. Sage Oaks, CA.

Evaristo, J. R., Scudder, R., Desouza, K. C. \& Sato, O. (2004). A dimensional analysis of geographically distributed project teams: a case study. Journal of Engineering and Technology Management. 21 (3), 175-189. http://dx.doi.org/10.1016/j.jengtecman.2003.05.001

Fellows, R. \& Liu, A. (2008) Research Methods for Construction. $3^{\text {rd }}$ Ed. Oxford: Wiley-Blackwell.

Ghanbari, A. (2006) Model Based Integrated Total Project Management System, with the Emphasis on Material Management. Ph.D. dissertation, the University of British Columbia.

Gruber, T. R. (1993). A translation approach to portable ontology's. Knowledge Acquisition. 5 (2), 199-220. http://dx.doi.org/10.1006/knac.1993.1008

Halfawy, M. M. R. (1998). A Multi Agent Collaborative Framework for concurrent Design of Constructed Facilities. Ph.D. dissertation, The Ohio State University.

Hamel, A., Pinson, S. \& Picard, M. (2005). A new approach to agency in a collaborative decision making process. International Conference on Intelligent Agent Technology. IEEE Computer Society19-22 Sept., pp. 273-276.

Howard, H. C., Levitt, R. E., Paulson, B. C., Pohl, J. G. \&, Tatum, C. B. (1989). Computer integration: reducing fragmentation in the AEC industry. Journal of Computing in Civil Engineering. 3, 18-31. http://dx.doi.org/10.1061/(ASCE)0887-3801(1989)3:1(18)

Huang, C. J., Trappey, A. J. C. \& Yao, Y-H. (2006) Developing an agent based workflow management systems for collaborative product design. Industrial Management \& Data Systems. 106 (5), 680-699. http://dx.doi.org/10.1108/02635570610666449

Jaapar, A., Endut, I. R., Bari, N. A. A. \& Takim, R, (2009) The impact of value management implementation in Malaysia. Journal of Sustainable Development. 2 (2), 210-216.

Jacobsen, M. (2004). Complementary Research Methods. SERN, University of Calgary.

Kaufman, J. J. (2001). Value Management: Creating Competitive Advantage. Financial World Publishing. Canterbury, Kent, UK.

Kaufman, J. J. \& McCuish, J. D. (2002). Getting better solutions with brainstorming. SAVE International Annual Conference Proceedings. Volume XXXVII, Denver, Colorado, 5-8 May.

Kelly, J., Male, S. \& Graham, D. (2004). Value Management of Construction Project. Blackwell Publishing, Oxford UK. http://dx.doi.org/10.1002/9780470773642

Kerzner, H. (2003). Project Management: A System Approach to Planning, Scheduling and Controlling. John Wiley and Sons. Hoboken, NJ.

Khedro, T. (1994). A Distributed Problem Solving Approach to Collaborative Facility Engineering Through Agent Based Software Integration. Ph.D. dissertation. Stanford University.

Kimchi, J., Polivka, B. \& Stevenson, J. S. (1991). Triangulation: operational definitions. Nursing Research. 40 (6), 364-366.

Kim, S. K. \& Russell, J. S. (2003). Framework for an intelligent earthwork system-part I. system architecture. 
Automation in Construction. 12 (1), 1-13. http://dx.doi.org/10.1016/S0926-5805(02)00034-1

King, G., Koehane, R. O. \& Verba, S. (1994). Designing Social Inquiry: Scientific Inference in Qualitative Research. Princeton University Press, Princeton, NJ.

Kirk, S. J. \& Spreckelmeyer, K. F. (1998). Enhancing Value in Design Decisions. Kirk Associates, Grosse Pointe Park, MI.

Kitamura, Y. \& Mizoguchi, R. (1999). An ontology of functional concept of artefacts. AI-TR 1.

Kumaraswamy, M. M., Ng, S T., Ugwu, O. O., Palaneeswaran, E. \& Rahman, M. M. (2004) Empowering collaborative decisions in complex construction project scenario. Engineering, Construction and Architectural Management. 11 (2), 122-142. http://dx.doi.org/10.1108/09699980410527876

Landaurer, J. \& Rowlands, J. (2006) Importance of Philosophy. [Online] Available: http://www. Importance ofphilosophy.com/Epistemology_Main.html. Cited on 25/3/2011.

Lenzer, B. (2001). 21st century corporate strategies to apply new value tools and techniques: an introduction to multi-dimensional decision analysis hybrid fast modeling, SAVE Conference. May $6-9^{\text {th }}$, Fort Lauderdale, Florida.

Leung, M. Y., Ng, S. T. \& Cheung, S. O. (2002). Improving satisfaction through conflict stimulation and resolution in value management. Journal of Management in Engineering. 18 (2), 68-75. http://dx.doi.org/10.1061/(ASCE)0742-597X(2002)18:2(68)

Lin, G. \& Shen, Q. (2007). Measuring the performance of value management studies in construction: critical review. Journal of Management in Engineering. 23 (1), 2-9. http://dx.doi.org/10.1061/(ASCE)0742-597X(2007)23:1(2)

Liu, G. (2003). A Framework for Implementing Value Management in China's Construction Industry. Ph.D. dissertation, Department of Building and Real Estate the Hong Kong Polytechnic University.

Li, Y., Shao, X., Li, P. \& Liu, Q. (2004). Design and implementation of a process-oriented intelligent collaborative product design system. Computers in Industry. 53 (2), 205-229. http://dx.doi.org/10.1016/S0166-3615(03)00146-5

Love, P. E. D., Holt, E. D. \& Li, H. (2002). Triangulation in construction management research. Engineering, Construction and Architectural Management. 9 (4), 294-303.

Matsatsinis, N. F. \& Delias, P. (2003). AgentAllocator: an agent-based multi-criteria decision support system for task allocation in V. Marik, D. McFarlane, P. Valckenaers (eds.), HoloMAS 2003, LNAI 2744, Springer-Verlag Berlin Heidelberg, pp. 225-235.

Morgan, G. \& Smircich, L. (1980). The case for qualitative research. Academy of Management Review. 5 (4), 491-500.

Morge, M. \& Beaune, P. (2004). A negotiation support system based on multi-agent system: specify \& preference relation on arguments. ACM Symposium on Applied Computing. Nicosia, Cyprus, March 14 - 17, pp. 474 - 478. http://dx.doi.org/10.1145/967900.967999

Mukhopadhyaya, A. K. (2003). Value Engineering: Concepts, Techniques and Applications. Response Books, New Delhi.

Ng, S. T., Skitmore, R. M. \& Leung, T. K. C. (2005). Manageability of stress among construction project participants. Engineering, Construction and Architectural Management. 12 (3), 264-282. http://dx.doi.org/10.1108/09699980510600125

Nidiffer, K. E. \& Dolan, D. (2005) Evolving distributed project management. IEEE Software. 22 (5), 63-72. http://dx.doi.org/10.1109/MS.2005.120

Parker, H. (2000). Interfirm collaboration and the new product development process. Industrial Management and Data System 100(6): 255-260. http://dx.doi.org/10.1108/02635570010301179

Pena-Mora, F. \& Wang, C-Y. (1998). Computer-supported collaborative negotiation methodology. Journal of Computing in Civil Engineering. 12 (2), 64-81. http://dx.doi.org/10.1061/(ASCE)0887-3801(1998)12:2(64)

Phillimore, J. \& Goodson, L. (2004). Qualitative Research: Ontologies, Epistemologies and Methodologies. Routledge, London.

Ren, Z. \& Anumba, C. J. (2004). Multi-agent systems in construction-state of the art and prospects. Automation 
in Construction. 13 (3), 421-434. Elsevier. http://dx.doi.org/10.1016/j.autcon.2003.12.002

SAVE International (2001). Value Methodology Standard. [Online] Available: Http://www.value-eng.org/manuals/ vmstd.pdf. Cited on 6 April 2009.

Sense, A. J. (2008). The conditioning of project participant's authority to learn within project. International Journal of Project Management. 26 (2), 105-111. http://dx.doi.org/10.1016/j.jproman.2007.09.008

Shen, Q. \& Liu, G. (2004). Applications of value management in the construction industry in China. Engineering, Construction and Architectural Management. 11(1): 9-191. http://dx.doi.org/10.1108/09699980410512629

Thurmond, V. A. (2001). The point of triangulation. Journal of Nursing Scholarship. 33 (3), 253-258. http://dx.doi.org/10.1111/j.1547-5069.2001.00253.x

Ugwu, O. O., Anumba, C. J., Newnham, L. \& Thorpe, A. (1999). Agent-based decision support for collaborative design and project management. The International Journal of Construction Information Technology. 7 (2), 1-16.

Venkataraman, R. R. \& Pinto, J. K. (2008). Cost and Value Management in Projects. New Jersey: John Wiley\&Sons, pp.163-184. http://dx.doi.org/10.1002/9780470261033.ch8

Vo, B. Q. \& Padgham, L. (2007). Searching for joint gains in automated negotiations based on multi-criteria decision making theory. Autonomous Agents and Multi Agent Systems (AAMAS), Hawaii, May.

Wan, Y. T. (2006). A Value Management Framework for Systematic Identification and Precise representation of Client Requirements in the Briefing Process. PhD. dissertation. The Hong Kong Polytechnic University. http://dx.doi.org/10.1016/j.jnca.2006.04.009

Wanyama, T. (2006). Decision Support for COTS Selection. Ph.D. dissertation, University of Calgary.

Wanyama, T. \& Far, B.H. (2007). A protocol for multi-agent negotiation in a group-choice decision making. Journal of Network and Computer Applications. 30, 1173-1195.

Woodhead, R. (2007). Concepts of value in value management: the relationship between function and value. Value World summer, SAVE International.

Younker, D. L. (2003). Value Engineering: Analysis and Methodology. Marcer Dekker, NY. http://dx.doi.org/10.1201/9780203912751 
Table 1. Research Methods Applied under Triangulation Methodology

\begin{tabular}{|c|c|c|c|}
\hline Method & Goal & Data Collection & Analysis and tools \\
\hline \multirow[t]{2}{*}{$\begin{array}{l}\text { Theoretical } \\
\text { Mapping }\end{array}$} & $\begin{array}{c}\text { To find theoretical basis for } \\
\text { NSVM }\end{array}$ & Literature & Literature review \\
\hline & $\begin{array}{l}\text { To develop research approach } \\
\text { for NSVM methodology }\end{array}$ & Previous related studies & \\
\hline \multirow[t]{3}{*}{$\begin{array}{l}\text { Conceptual } \\
\text { modeling }\end{array}$} & $\begin{array}{l}\text { To develop conceptual model of } \\
\text { negotiation support for value } \\
\text { management }\end{array}$ & $\begin{array}{l}\text { Model of style and } \\
\text { outcome from survey. }\end{array}$ & $\begin{array}{l}\text { Prometheus Design } \\
\text { Tools (PDT) for: }\end{array}$ \\
\hline & & $\begin{array}{l}\text { Qualitative method to } \\
\text { collect idea. }\end{array}$ & $\begin{array}{l}\text { Developing system } \\
\text { specification, } \\
\text { Architectural design, } \\
\text { Detail design and }\end{array}$ \\
\hline & & $\begin{array}{l}\text { Algorithm of agreement } \\
\text { options, coalition } \\
\text { formation and trade off. }\end{array}$ & $\begin{array}{l}\text { Checking for } \\
\text { Completeness and } \\
\text { Consistency }\end{array}$ \\
\hline \multirow[t]{2}{*}{ Survey } & $\begin{array}{l}\text { To investigate the negotiation } \\
\text { style and outcome on } \\
\text { construction practice }\end{array}$ & $\begin{array}{l}\text { Questionnaire by mail } \\
\text { and email }\end{array}$ & $\begin{array}{l}\text { Multiple regression } \\
\text { analysis, ANOVA, } \\
\text { F-test, t-test. }\end{array}$ \\
\hline & $\begin{array}{l}\text { To develop correlation model } \\
\text { between style and outcome }\end{array}$ & & \\
\hline Focus group & $\begin{array}{l}\text { To determine the function of a } \\
\text { building system }\end{array}$ & $\begin{array}{l}\text { Group discussion, } \\
\text { brainstorming, note. }\end{array}$ & $\begin{array}{l}\text { Function Analysis } \\
\text { System Technique }\end{array}$ \\
\hline \multirow[t]{5}{*}{ Case study } & $\begin{array}{l}\text { To investigate individual and } \\
\text { group decision preference } \\
\text { among stakeholders in design }\end{array}$ & $\begin{array}{l}\text { Questionnaire pair wise } \\
\text { comparison }\end{array}$ & $\begin{array}{l}\text { Analytical Hierarchy } \\
\text { Process: }\end{array}$ \\
\hline & & & $\begin{array}{c}\text { Pair wise comparison } \\
\text { analysis, }\end{array}$ \\
\hline & & & Normalization, \\
\hline & & & Consistency analysis \\
\hline & & & $\begin{array}{l}\text { Group preferences } \\
\text { analysis }\end{array}$ \\
\hline
\end{tabular}




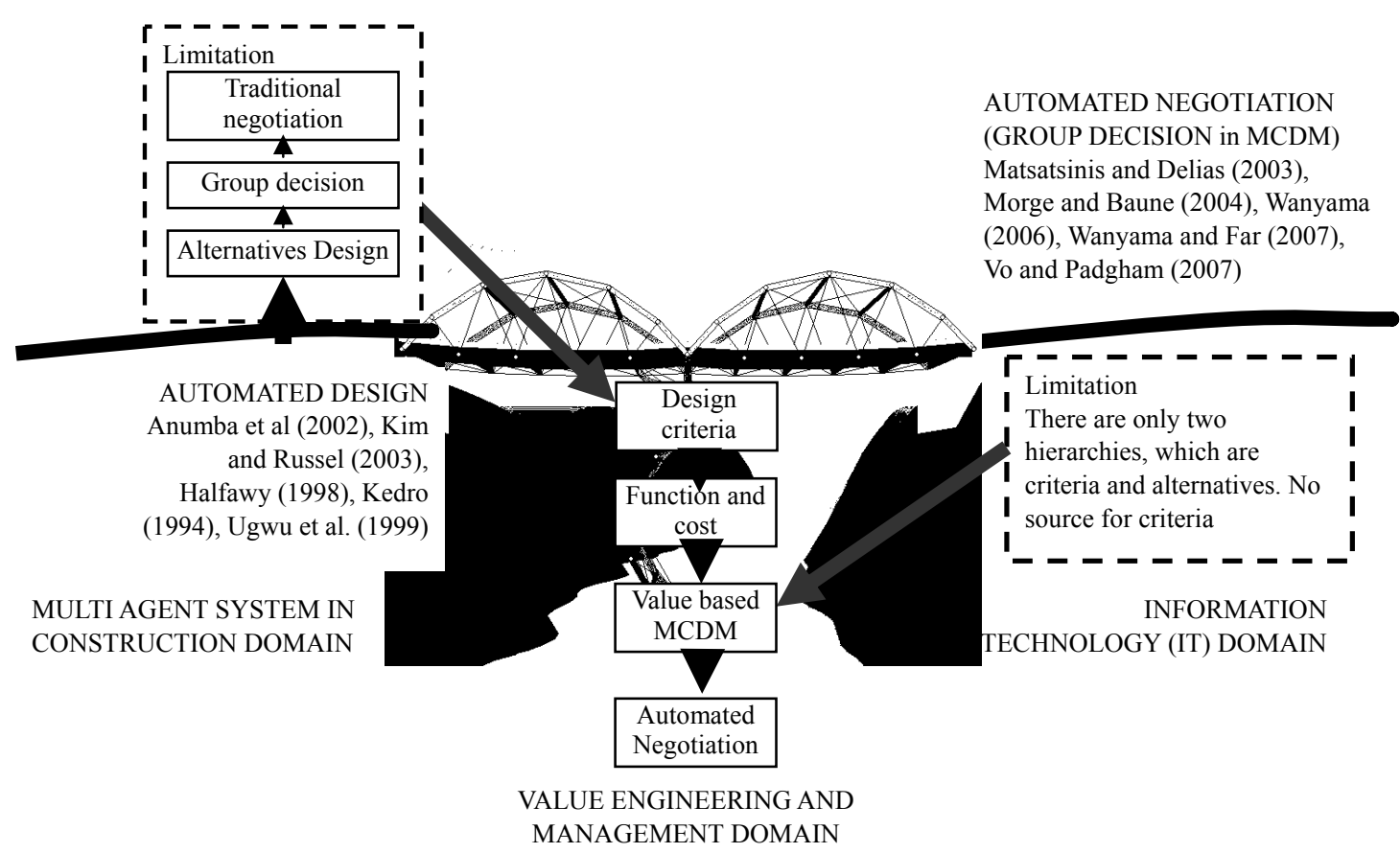

Figure 1. Bridging a Theoretical Gap between Automated Design in Construction Domain and Automated Negotiation in IT Domain 